\title{
MORFOMETRI CANGKANG PADA GENUS Strombus DAN Cerithidea DI PANTAI KOTA TERNATE SELATAN
}

\author{
Iklima Ishak ${ }^{1}$, Zulkifli Ahmad², Ade Haerullah² \\ ${ }^{1}$ Alumni Pendidikan Biologi FKIP Universitas Khairun, Jl. Bandara Babullah, Kampus I \\ Akehuda, Ternate. HP: 082196510406, E-mail: iklimahishak@yahoo.co.id. \\ 2Dosen Pendidikan Biologi FKIP Universitas Khairun
}

\begin{abstract}
Abstrak
Gastropoda merupakan salah satu sumber daya hayati yang banyak dimanfaatkan oleh masyarakat. Cangkang gastropoda sudah terpilin sejak masa embrio. Gastropoda umumnya bercangkang tunggal yang terpilin membentuk spiral dengan bentuk dan warna yang beragam. Penelitian ini bertujuan untuk mencandra morfometri dan mendeskripsikan non-morfometri cangkang pada genus Strombus dan Cerithidea di tiga lokasi sampling, yakni pantai Bastiong, Fitu, dan Jambula dengan metode survei jelajah bebas. Teknik pengumpulan data meliputi morfometrik dan non morfometrik. Hasil penelitian genus Strombus dan Cerithidea ditemukan sebanyak 111 individu dari 14 jenis yang teridentifikasi. Parameter morfometri genus Strombus dan Cerithidea yang ditemukan di tiga lokasi sampling menunjukkan Panjang Cangkang (PC), Lebar Cangkang (LC), Lebar Kolumela (LK), Tinggi Aperture (TA) dan Lebar Aperture (LA) yang berbeda-beda, serta pengamatan non-morfometrik pada genus Strombus, berupa tipe cangkangnya concentric dan putaran cangkang sinistral, sedangkan pada genus Cerithidea tipe cangkangnya multispiral dan arah putaran dekstral. Kedua genus tersebut memiliki warna dan bentuk yang beragam.
\end{abstract}

Kata Kunci: Cangkang, Cerithidea, Kota Ternate, Morfometri, Strombus

\section{PENDAHULUAN}

Gastropoda merupakan salah satu sumber daya hayati yang banyak dimanfaatkan oleh masyarakat Indonesia sebagai bahan makanan sumber protein yang bernilai ekonomis penting (Dharma, 2005). Gastropoda merupakan kelas terbesar dari Mollusca, yang telah terindentifikasi lebih dari 75.000 jenis, dan 15.000 di antaranya ditemukan dalam bentuk fosil.

Cangkang gastropoda terdiri dari 4 lapisan. Paling luar adalah periostrakum, yang merupakan lapisan tipis terdiri dari bahan protein seperti zat tanduk, disebut conchiolin atau conchin. Pada lapisan ini terdapat endapan pigmen yang beraneka warna, yang menjadikan banyak cangkang siput terutama spesis laut sangat indah warnanya, terdiri dari warna kuning, hijau, cemerlang dengan bercak-bercak merah atau garis-garis cerah. Jenis gastropoda di habitat air tawar, umumnya berwarna kusam. Periostrakum berfungsi untuk melindungi lapisan di bawahnya terdiri dari kalsium karbonat yang tahan terhadap erosi (Suwignyo dkk, 2005).

Dalam pembelajaran mengenai gastropoda, morfologi cangkang selalu diperkenalkan. Hal tersebut berkaitan dengan penggunaan karakter untuk identifikasi, dan menjelaskan keragaman morfologi, serta ekologi gastropoda. Beberapa kesulitan sering muncul dalam mempelajari cangkang gastropoda. Fenomena tersebut terjadi sebagai akibat modifikasi beberapa karakter cangkang dan morfologi tipikalnya. Beberapa struktur varian cangkang yang sering dijumpai misalnya pewarnaan, ataupun mereduksinya beberapa karakter. Kasus 


\section{TECHNO: Vol. 07 ( 02) Oktober 2018}

modifikasi tersebut dapat berakibat pada kesalahan intepretasi dan identifikasi (Karyanto dkk, 2004).

Penelitian perlu dilakukan agar memudahkan mahasiswa atau peneliti lain dalam menentukan jenis berdasarkan karakter morfologi cangkang gastropoda.

\section{MATERI DAN METODE}

Materi yang digunakan dalam penelitian ini adalah sampel genus Strombus dan Cerithidea yang diambil di perairan pantai Bastiong, Fitu, dan Jambula. Penelitian ini dilakukan dengan tipe penelitian deskriptif yaitu penelitian yang berusaha menggambarkan atau menginterpretasikan objek sesuai apa yang saat ini berlaku (Sukardi, 2009). Identifikasi morfometrik dan non-morfometrik genus Strombus dan genus Cerithidea yang diambil dari tiga lokasi sampling, dilakukan di Laboratorium MIPA FKIP Universitas Khairun. Pengambilan data menggunakan metode jelajah bebas. Lokasi penelitian ditentukan sebanyak tiga stasiun pengamatan, dengan masing-masing stasiun luasnya $60 \mathrm{~m}^{2}$ di daerah intertidal. Sampel diambil secara beraturan, mengikuti garis zigzag dan dilakukan pada saat air surut. Sampel gastropoda yang ditemukan dalam lokasi diambil lalu dicatat, kemudian dimasukkan ke dalam kantung plastik yang diberi label, setelah itu diidentifikasi jenis dan dikelompokkan ke dalam dua genus berdasarkan petunjuk (Mujiono, 2011).

\section{HASIL DAN PEMBAHASAN}

Berdasarkan hasil analisis data tentang jumlah genus Strombus dan Cerithidea di temukan dari tiga lokasi sebanyak 83 individu yang tergolong genus Strombus dan sebanyak 28 individu yang tergolong genus Cerithidea. Total jenis yang ditemukan di tiga lokasi sejumlah 14 jenis dengan total individu adalah 111. Dari tiga lokasi sampling, jenis yang sering dijumpai muncul di tiga lokasi tersebut adalah Strombus microurceus, Strombus luhuanus, Strombus urceus, dan Strombus labiatus.

\section{Morfometri Cangkang genus Stombus dan Cerithidea di Lokasi Sampling}

Berdasarkan hasil pengukuran morfometri cangkang dari genus Strombus dan genus Cerithidea di tiga lokasi sampling meliputi panjang cangkang, lebar cangkang, lebar kolumela, tinggi aperture, dan lebar aperture dapat dilihat pada Tabel 1 berikut ini.

Tabel 1. Data Morfometri Cangkang genus Strombus dan Cerithidea di tiga lokasi sampling

\begin{tabular}{llllll}
\hline Nama Genus & \multicolumn{1}{c}{ PC $(\mathbf{m m})$} & \multicolumn{1}{c}{ LC $(\mathbf{m m})$} & \multicolumn{1}{c}{ LK $(\mathbf{m m})$} & \multicolumn{1}{c}{ TA $(\mathbf{m m})$} & LA (mm) \\
\hline Srombus & $3.0-3.8$ & $1.5-3.0$ & $2.3-2.4$ & $1.9-2.4$ & $0.8-1.0$ \\
& $3.49 \pm 0.81$ & $3.01 \pm 4.16$ & $2.68 \pm 2.22$ & $2.57 \pm 2.66$ & $0.82 \pm 0.64$ \\
Cerithidea & $2.2-2.5$ & $2.1-2.2$ & $1.5-1.7$ & $1.1-1.3$ & $0.7-0.9$ \\
& $3.47 \pm 4.82$ & $2.08 \pm 2.87$ & $1.43 \pm 2.17$ & $1.22 \pm 2.15$ & $0.71 \pm 1.22$ \\
\end{tabular}

Keterangan: Panjang cangkang (PC), Lebar cangkang (LC), Lebar kolumela (LK), Tinggi Aperture (TA), Lebar Aperture (LA). Kisaran hasil pengukuran, Rata-rata dan Standar Deviasi.

Hasil pengukuran morfometri genus Strombus dan Cerithidea di tiga lokasi sampling ditemukan sebanyak 14 jenis yakni Strombus luhuanus, Strombus urceus, Strombus microurceus, 
Strombus ochroglottis, Strombus mutabilis, Strombus labiatus, Cerithidea cingulata, Cerithidea alata, Terebra subulata, Cerithidea palustris, Tympanotonus beberkirianus, Telescopium sp, Rhinoclavis aspera, dan Terebralia sulcata. Genus Strombus dan Cerithidea di atas setelah dilakukan pengukuran secara morfometrik masing masing memiliki ukuran panjang cangkang, lebar cangkang, tinggi aperture, lebar aperture dan lebar kolumela yang berbeda-beda.

\section{Non Morfometrik Cangkang genus Stombus dan Cerithidea di Tiga Lokasi Sampling}

Berdasarkan hasil pengamatan Non morfometri cangkang dari genus Strombus dan Cerithidea di tiga lokasi sampling meliputi putaran cangkang, warna, tipe cangkang dan bentuk yang beragam. Hasil pengamatan non morfometri terlihat bahwa masing-masing genus memiliki bentuk, putaran cangkang, tipe cangkang, dan warna yang bervariasi. Genus Srombus dan Cerithidea yang ditemukan memiliki arah putaran cangkang sinistral-dekstral dan tipe cangkang consentric-multispiral.

3. Parameter Lingkungan di tiga Lokasi Sampling

Hasil pengukuran parameter lingkungan dapat dilihat pada Tabel 2 berikut.

Tabel 2. Pengukuran Faktor Lingkungan

\begin{tabular}{|c|c|c|c|c|c|c|c|c|c|}
\hline \multirow{3}{*}{ Faktor Lingkungan } & \multicolumn{9}{|c|}{ LOKASI } \\
\hline & \multicolumn{3}{|c|}{ Stasiun 1} & \multicolumn{3}{|c|}{ Stasiun 2} & \multicolumn{3}{|c|}{ Stasiun 3} \\
\hline & $\begin{array}{c}08.00 \\
\text { wit }\end{array}$ & $\begin{array}{c}11.00 \\
\text { wit }\end{array}$ & $\begin{array}{c}16.00 \\
\text { wit }\end{array}$ & $\begin{array}{c}08.00 \\
\text { wit }\end{array}$ & $\begin{array}{c}11.00 \\
\text { wit }\end{array}$ & $\begin{array}{c}16.00 \\
\text { wit }\end{array}$ & $\begin{array}{c}08.00 \\
\text { wit }\end{array}$ & $\begin{array}{c}11.00 \\
\text { wit }\end{array}$ & $\begin{array}{c}16.00 \\
\text { wit }\end{array}$ \\
\hline Suhu $\left({ }^{0} \mathrm{C}\right)$ & 29 & 30 & 29 & 28 & 30 & 29 & 29 & 31 & 29 \\
\hline Salinitas (\%o) & 31.0 & 30.4 & 30.6 & 30.8 & 30.7 & 30.5 & 30.8 & 30.8 & 30.8 \\
\hline pH & 4 & 4.1 & 4.2 & 4.9 & 4.1 & 4.2 & 4.8 & 4.8 & 4.8 \\
\hline
\end{tabular}

Keterangan: Hasil pengukuran lingkungan di pantai Bastiong, Fitu, dan Jambula

Hasil pengukuran parameter lingkungan perairan di tiga lokasi sampling (suhu, pH, salinitas), masih berada pada kisaran normal untuk mendukung kehidupan biota laut, dan parameter lingkungan terukur belum dikatakan menjadi faktor pembatas terhadap aktivitas genus Strombus dan Cerithidea.

\section{PEMBAHASAN}

Berdasarkan hasil pengukuran morfometrik dan non morfometrik di Bastiong, Fitu, dan Jambula dapat dilihat perbedaan pengukuran cangkang. Cangkang memiliki variasi yang beragam, arah putaran cangkang umumnya ke arah kanan (dekstral) dan umumnya dilengkapi dengan operkulum. Tipe cangkang yang berputar ke arah kiri (sinistral) umumnya dijumpai pada kebanyakan gastropoda terestrial seperti pada genus Cerithidea (Aprilliani, 2011).

Pada penelitian ini ditemukan sebanyak 14 jenis dari genus Strombus dan Cerithidea yang ditemukan dengan uraian sebagai berikut.

\section{Cangkang Strombus luhuanus}

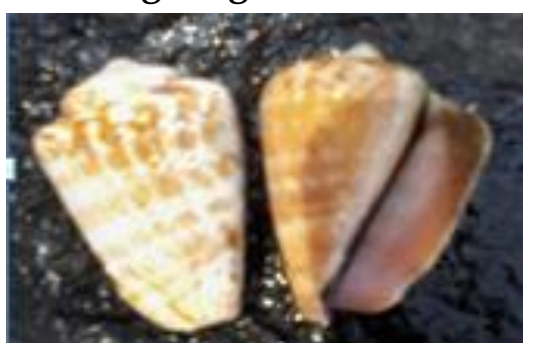

Gambar 1. Bentuk Cangkang Strombus luhuanus
Jenis ini ditemukan di tiga lokasi sampling yang telah diukur morfometri dan mengamati non-morfometrinya. Strombus luhuanus ini ditemukan di pantai Bastiong sebanyak 4 individu, di pantai Fitu sebanyak 10 individu, dan di pantai Jambula sebanyak 10 individu. Rerata panjang cangkang genus ini $5.0 \mathrm{~mm}$, rerata lebar cangkang $4.8 \mathrm{~mm}$, rerata lebar kolumela $4.5 \mathrm{~mm}$, rerata tinggi aperture $4.1 \mathrm{~mm}$, dan rerata lebar aperture $1.0 \mathrm{~mm}$. 
Strombus memiliki tipe cangkang consentric arah putaran cangkang sinistral. Pada masingmasing jenis yang ditemukan memiliki motif cangkang berwarna kuning keputihan dihiasi bercak coklat, bentuk oval, permukaan cangkang halus dan licin.

\section{Cangkang Strombus urceus}

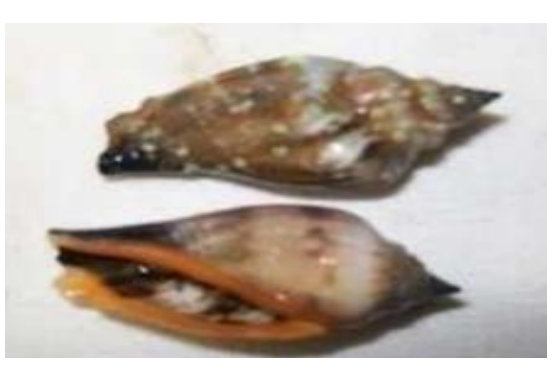

Gambar 2. Bentuk Cangkang Strombus urceus
Jenis Strombus urceus ini ditemukan dari pantai Fitu dan Jambula yang diukur morfometri dan mengamati nonmorfometrinya. Di lokasi Fitu ditemukan sebanyak 10 individu, dan di Jambula sebanyak 10 individu. Rerata panjang cangkang genus ini $3.8 \mathrm{~mm}$, rerata lebar cangkang $3.0 \mathrm{~mm}$, rerata lebar kolumela $2.4 \mathrm{~mm}$, rerata tinggi aperture $2.4 \mathrm{~mm}$, dan rerata lebar aperture $1.0 \mathrm{~mm}$. Strombus urceus ini memiliki tipe cangkang sinistral arah putaran cangkang concentric.

Pada masing-masing jenis yang ditemukan memiliki motif cangkang berwarna coklat hitam keabu-abuan, bentuk oval permukaan cangkang terdapat tonjolan-tonjolan berwarna keabuabuan.

\section{Cangkang Strombus microurceus}

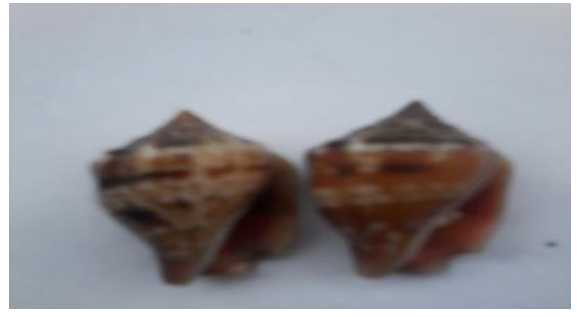

Gambar 3. Bentuk Cangkang

Strombus microurceus
Jenis ini diambil pantai Fitu dan Jambula yang diukur morfometri dan mengamati non-morfometrinya. Di pantai Fitu ditemukan sebanyak 14 individu, dan di Jambula sebanyak 12 individu. Rerata panjang cangkang genus ini $3.9 \mathrm{~mm}$, rerata lebar cangkang $3.1 \mathrm{~mm}$, rata-rata lebar kolumela $2.4 \mathrm{~mm}$, rerata tinggi aperture $2,5 \mathrm{~mm}$, dan rerata lebar aperture $1.0 \mathrm{~mm}$.

Strombus microurceus ini memiliki tipe operculum sinistral arah putaran cangkang concentric. Pada masing-masing jenis yang ditemukan memiliki motif cangkang berwarna krem coklat kehitaman, bentuk oval permukaan cangkang licin.

\section{Cangkang Strombus ochroglottis}

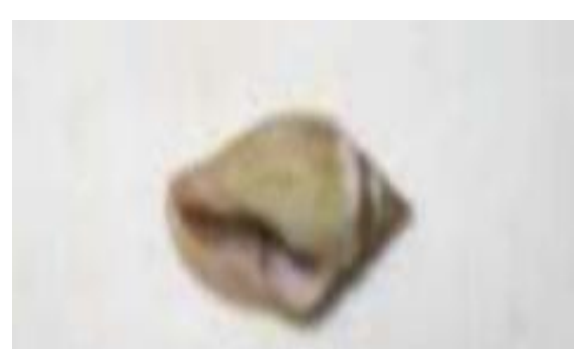

Gambar 4. Bentuk Cangkang Strombus ochroglottis
Jenis ini ditemukan di pantai Fitu sebanyak 1 individu yang diukur morfometri dan mengamati non morfometrinya. Rerata panjang cangkang genus ini 2.0 $\mathrm{mm}$, rerata lebar cangkang $1.5 \mathrm{~mm}$, rerata lebar kolumela $1.7 \mathrm{~mm}$, rerata tinggi aperture $1.9 \mathrm{~mm}$, dan rerata lebar aperture $0.5 \mathrm{~mm}$. Tipe operculum sinistral, dan arah putaran cangkang concentric. Jenis ini memiliki motif cangkang berwarna hijau coklat, putih kehitaman, bentuk oval permukaan cangkang halus dan berlumut. 


\section{Cangkang Strombus mutabilis}

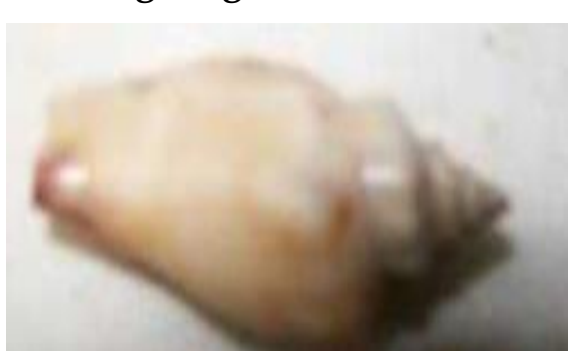

Gambar 5. Bentuk Cangkang Strombus mutabilis

\section{Cangkang Strombus labiatus}

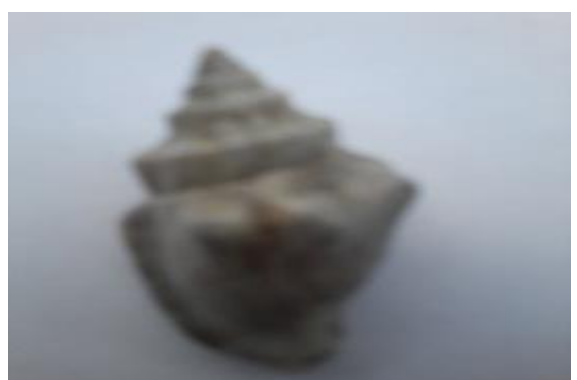

Gambar 6. Bentuk Cangkang

Strombus labiatus
Jenis ini ditemukan di pantai Fitu ditemukan sebanyak 1 individu yang diukur morfometri dan mengamati nonmorfometrinya. Rerata panjang cangkang genus ini 4.5 $\mathrm{mm}$, rerata lebar cangkang $4.4 \mathrm{~mm}$, rerata lebar kolumela $4.5 \mathrm{~mm}$, rerata tinggi aperture $4.2 \mathrm{~mm}$, dan rerata lebar aperture $1.0 \mathrm{~mm}$. Tipe operculum sinistral, dan arah putaran cangkang concentric. Jenis ini memiliki motif cangkang berwarna kuning coklat keabu-abuan, bentuk oval permukaan cangkangnya menonjol dan kasar.

Jenis Strombus labiatus ini ditemukan di pantai Fitu sebanyak 6 individu, dan Jambula sebanyak 5 individu. Rerata panjang cangkang genus ini $3.7 \mathrm{~mm}$, rerata lebar cangkang $3.0 \mathrm{~mm}$, rerata lebar kolumela $2.2 \mathrm{~mm}$, rerata tinggi aperture $2.0 \mathrm{~mm}$, dan rerata lebar aperture $1.0 \mathrm{~mm}$. Tipe cangkang sinistral, dan arah putaran cangkang concentric. Jenis ini memiliki motif cangkang berwarna krem kecoklatan, bentuk persegi tiga permukaan cangkang kasar dengan ujungnya menonjol.

\section{Cangkang Cerithidea cingulata}

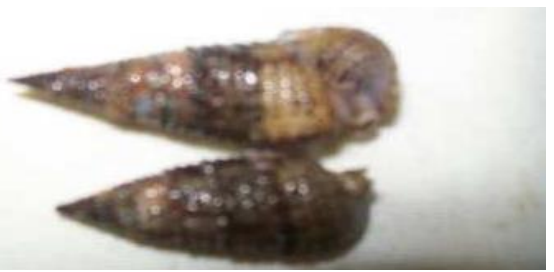

Gambar 7. Bentuk cangkang Cerithidea cingulata
Jenis Cerithidea cingulata ditemukan di pantai Bastiong sebanyak 2 individu, dan pantai Fitu sebanyak 5 individu. Rerata panjang cangkang $2.5 \mathrm{~mm}$, rerata lebar cangkang 2.2 $\mathrm{mm}$, rerata lebar kolumela $1.7 \mathrm{~mm}$, rerata tinggi aperture $1.13 \mathrm{~mm}$, dan rerata lebar aperture $0.9 \mathrm{~mm}$. Tipe cangkang umumnya dekstral, dan arah putaran cangkang multispiral.

Jenis ini memiliki motif cangkang berwarna kuning coklat kehitaman berbintik-bintik, bentuk kerucut dengan ujungnya menyempit membentuk sudut, permukaan cangkang berbintik coklat hitam.

\section{Cangkang Cerithidea alata}

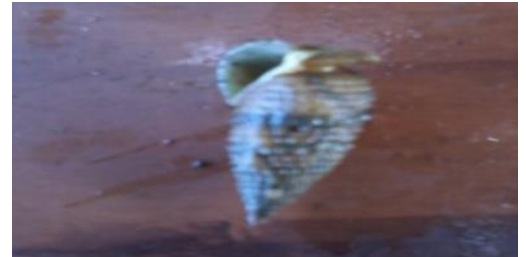

Gambar 8. Bentuk cangkang Cerithidea alata
Jenis ini ditemukan di pantai Fitu sebanyak 5 individu yang telah diukur morfometri dan mengamati non-morfometrinya. Rata-rata panjang cangkang Cerithidea alata ini $3.0 \mathrm{~mm}$, ratarata lebar cangkang $1.5 \mathrm{~mm}$, rata-rata lebar kolumela $2.1 \mathrm{~mm}$, rata-rata tinggi aperture $2.3 \mathrm{~mm}$, dan lebar aperture rata-rata 0.9 $\mathrm{mm}$.

Cerithidea alata ini memiliki tipe operculum dekstral dan arah putaran cangkang multispiral. Pada masing-masing jenis yang ditemukan memiliki motif cangkang berwarna hijau krem 
kecoklatan, bentuk kerucut dengan sudut runcing menyempit, permukaan cangkang berbintik-bintik.

\section{Cangkang Terebra subulata}

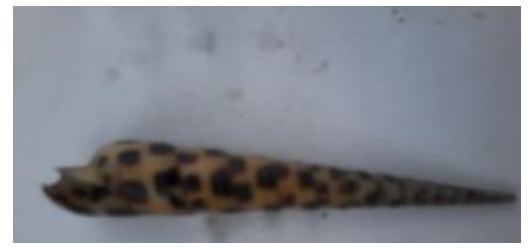

Gambar 9. Bentuk cangkang Terebra subulata

Jenis ini ditemukan di pantai Fitu sebanyak 2 individu yang telah diukur morfometri dan mengamati non-morfometrinya. Rata-rata panjang cangkang Terebra subulata ini $7.5 \mathrm{~mm}$, ratarata lebar cangkang $1.5 \mathrm{~mm}$, rata-rata lebar kolumela $0.5 \mathrm{~mm}$, rata-rata tinggi aperture $0.4 \mathrm{~mm}$, dan lebar aperture rata-rata 0.3 $\mathrm{mm}$. Jenis ini memiliki tipe operculum dekstral, dan arah putaran cangkang multispiral.

Pada masing-masing jenis Terebra subulata yang ditemukan memiliki motif cangkang berwarna kuning kecoklatan dihiasi bintik-bintik hitam, bentuk panjang, permukaan cangkang licin yang dihiasi bintik-bintik hitam dengan ujungnya menyempit.

\section{Cangkang Cerithidea palustris}

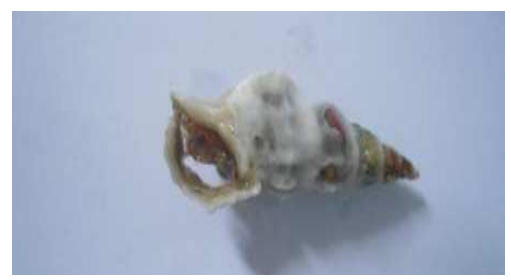

Jenis ini ditemukan di pantai Fitu sebanyak 1 individu yang telah diukur morfometri dan mengamati non-morfometrinya. Rata-rata panjang cangkang Cerithidea palustris ini $2.5 \mathrm{~mm}$, rata-rata lebar cangkang $1.0 \mathrm{~mm}$, rata-rata lebar kolumela 0.7 $\mathrm{mm}$, rata-rata tinggi aperture $0.9 \mathrm{~mm}$, dan lebar aperture ratarata $0.4 \mathrm{~mm}$. Cerithidea palustris ini memiliki tipe operculum dekstral dan arah putaran cangkang multispiral.

Gambar 10. Bentuk cangkang Pada masing-masing jenis yang ditemukan memiliki motif Cerithidea palustris ijau kecoklatan, bentuk oval dengan ujungnya menyempit cangkang berwarna putih hijau kecoklatan, be
membentuk sudut, permukaan cangkang menonjol.

\section{Cangkang Tympanotonus beberkirianus}

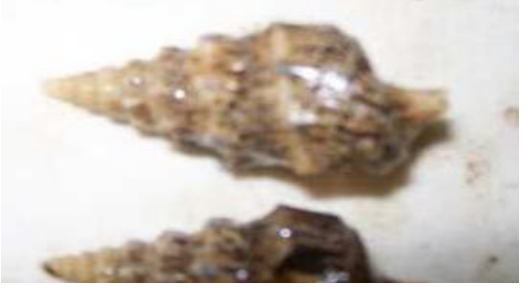

Gambar 11. Bentuk cangkang Tympanotonus beberkirianus
Jenis ini ditemukan di pantai Fitu sebanyak 2 individu yang diukur morfometri dan mengamati non morfometrinya. Ratarata panjang cangkang Tympanotonus beberkirianus ini $3.0 \mathrm{~mm}$, rata-rata lebar cangkang $2.9 \mathrm{~mm}$, rata-rata lebar kolumela 1.9 $\mathrm{mm}$, rata-rata tinggi aperture $1.0 \mathrm{~mm}$, dan lebar aperture ratarata $0.5 \mathrm{~mm}$. Jenis ini memiliki tipe operculum dekstral dan arah putaran cangkang multispiral.

g ditemukan memiliki motif cangkang berwarna coklat muda berbintik hitam, bentuk kerucut melingkar dengan ujungnya menyempit, permukaan cangkang menonjol.

\section{Cangkang Telescopium sp}

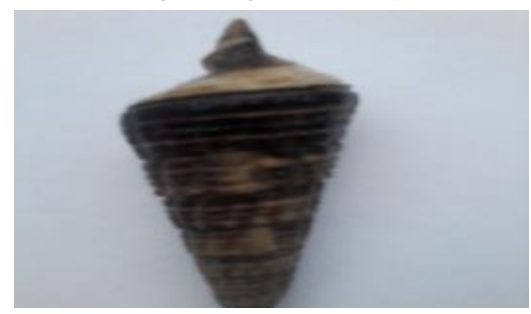

Jenis Telescopium sp ditemukan di pantai Fitu sebanyak 2 individu yang diukur morfometri dan mengamati nonmorfometrinya. Rata-rata panjang cangkang genus ini $7.3 \mathrm{~mm}$, rata-rata lebar cangkang $4.0 \mathrm{~mm}$, rata-rata lebar kolumela 2.3 $\mathrm{mm}$, rata-rata tinggi aperture $2.0 \mathrm{~mm}$, dan lebar aperture rata- 
rata $1.0 \mathrm{~mm}$. Telescopium telescopium sp ini memiliki tipe operculum dekstral dan arah putaran cangkang multispial.

Pada masing-masing jenis Telescopium sp yang ditemukan, memiliki motif cangkang berwarna krem coklat kehitaman, bentuk kerucut memanjang, melingkar dengan ujungnya menyempit dan permukaan cangkang kasar.

\section{Cangkang Rhinoclavis aspera}

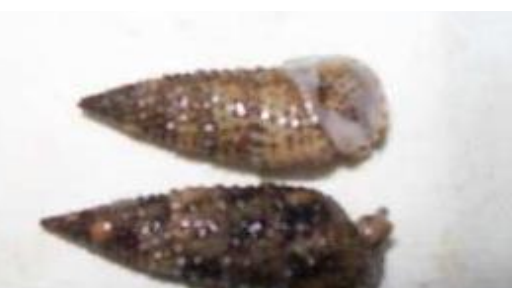

Gambar 13. Bentuk cangkang Rhinoclavis aspera

Jenis Rhinoclavis aspera ini ditemukan di pantai Fitu dan Jambula masing-masing 2 individu, yang telah diukur morfometri dan mengamati non-morfometrinya. Rata-rata panjang cangkang genus ini $2.0 \mathrm{~mm}$, rata-rata lebar cangkang $1.8 \mathrm{~mm}$, rata-rata lebar kolumela $1.5 \mathrm{~mm}$, rata-rata tinggi aperture $1.3 \mathrm{~mm}$, dan lebar aperture rata-rata $1.0 \mathrm{~mm}$. Rhinoclavis aspera ini memiliki tipe operculum dekstral dan arah putaran cangkang multispiral.

Pada masing-masing jenis Rhinoclavis aspera yang ditemukan memiliki motif cangkang berwarna coklat muda kehitaman berbintik kehitaman bentuk kerucut dengan ujungnya menyempit, permukaan berbintik-bintik.

\section{Cangkang Terebralia sulcata}

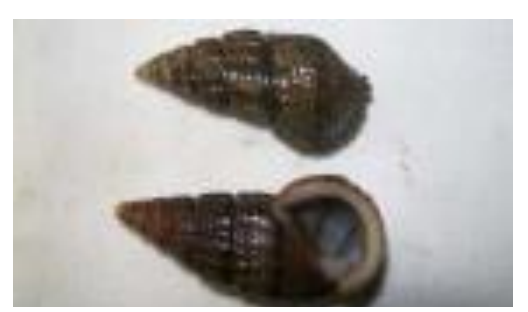

Gambar 14. Bentuk cangkang Terebralia Sulcata
Jenis Terebralia sulcata ini ditemukan dari pantai Fitu dan Jambula yang diukur morfometri dan mengamati nonmorfometrinya. Jenis yang ditemukan di pantai Fitu sebanyak 3 individu dan di Jambula sebanyak 2 individu. Rata-rata panjang cangkang genus ini $3.6 \mathrm{~mm}$, rata-rata lebar cangkang $2.5 \mathrm{~mm}$, rata-rata lebar kolumela $1.5 \mathrm{~mm}$, rata-rata tinggi aperture $1.3 \mathrm{~mm}$, dan lebar aperture rata-rata $1.0 \mathrm{~mm}$.

Jenis ini memiliki tipe operculum dekstral dan arah putaran cangkang multispiral. Pada masing-masing jenis Terebralia sulcata yang ditemukan memiliki motif cangkang berwarna coklat kehitaman berbintik-bintik, bentuk kerucut melingkar dengan ujungnya membentuk sudut, permukaan berbintik-bintik.

\section{KESIMPULAN}

Berdasarkan hasil penelitian di pantai Bastiong, pantai Fitu, dan pantai Jambula Kota Ternate Selatan dapat disimpulkan bahwa:

1. Pengukuran morfometri genus Strombus dan Cerithidea yang ditemukan di ketiga lokasi meliputi Panjang Cangkang (PC), Lebar Cangkang (LC), Lebar Kolumela (LK), Tinggi aperture (TA) dan Lebar Aperture (LA) yang berbeda-beda.

2. Pengamatan non morfometrik yang terdapat pada genus Strombus, tipe cangkang concentric dan putaran cangkang sinistral, sedangkan genus Cerithidea tipe cangkang multispiral dan arah putaran dekstral yang mempunyai warna dan bentuk yang beragam. 


\section{DAFTAR PUSTAKA}

Clemente, S. 2011. Recruitment of Mud Clam Polymesoda erosa (Solander, 1876) in a Mangrove Habitat of Chorao Island, Goa. Brazilian Journal of Oceanography.

Dody, S. 2010. Morfometrik dan Pertumbuhan Kerang Tapes (Tapes literatus) di Pulau Fair, Maluku Tenggara. Prosiding Seminar Riptek Kelautan Nasional, Ancol Timur. Jakarta.

Karyanto, P. M. dan Meti I. 2004. Variasi cangkang gastropoda ekosistem mangrove cilacap sebagai sumber pembelajaran moluska; Gastopoda. Pendidikan Biologi FKIP Universitas Sebelas Maret

Komala, R, F.Yulianda, dan D.Lumbanbatu. 2011 Morfometri Kerang Anadara granosa dan anadara antiquate pada Wilayah yang Tereksploitasi di Teluk Lada di perairan Selatan Sunda. Jurnal Pertanian-UMMI.

Mujiono. N. 2011. Studi Variasi Motif Dan Morfometri Cangkang Pada Clithon oualaniensis (Gastropoda: Neritidae) Di Indonesia. Pusat Penelitian Biologi-LIPI.

Nontji. 1987. Laut Nusantara. Djambatan. Jakarta

Rizkya , S., Siti.R., Max, R.M. 2012. Studi kelimpahan Gastrropoda (Lambis spp). Pada Daerah Makro Alga Di pulau Pramuka, Kepulauan Seribu. J. Of management of aquatic resources.

Rusnaningsih. 2012. Struktur Komunitas Gastropoda dan Studi Populasi Cerithidea Obtusa (Lamarck 1822) di Hutan Mangrove Pangkal Babu Kabupaten Tanjung Jabung Barat, Jambi. [Tesis]. Pascasarjana Universitas Indonesia. Depok.

Siddik, J. 2011. Sebaran Spasial Dan Potensi Reproduksi Populasi Siput Gonggong (Strombus turturela) Di Teluk Klabat Bangka-Belitung. [Tesis]. Institut Pertanian Bogor.

Suwignyo S, Bambang W, Yusli W, Majariana K. 2005. Avertebrata Air jilid 1. Jakarta. Penebar Swadaya.

Tamsar, Emiyarti, dan Nurgaya, W., 2013, Studi Laju Pertumbuhan dan Tingkat Eksploitasi Kerang Kalandue (Polymesoda erosa) Pada Daerah Hutan Mangrove di Teluk Kendari. Jurnal Mina Laut Indonesia 